\title{
2 Civic and Citizenship Framework
}

\subsection{Defining civics and citizenship}

\subsubsection{The scope of civics and citizenship in ICCS 2016}

The civic and citizenship framework identifies and defines those aspects of cognitive and affective-behavioral content ${ }^{3}$ that should be considered important learning outcomes of civic and citizenship education. It should be noted that within the context of this framework the term "learning outcomes" is used in a broad way and is not confined to school learning. The way students develop cognitive knowledge and understanding of civics and citizenship, as well as affective-behavioral dispositions towards civics and citizenship, may depend on many factors beyond their learning environment at school (see Amnå, Ekström, Kerr, \& Stattin, 2009; Pancer, 2015; Pancer, \& Pratt, 1999). The factors influencing students' development of these learning outcomes are mapped and described in the contextual framework.

The conception of civic and citizenship education underpinning ICCS 2016 places the central focus on the individual student who is influenced by "agents of socialization" in varied learning environments (Torney-Purta et al., 2001). It reflects a view that learning about civics and citizenship is not limited to instruction in schools but is an outcome from a range of processes that take place in different environments. Young people learn about civics and citizenship through their interactions with a range of significant others and the various communities with which they are associated. This view has continued through the predecessors of ICCS 2016: CIVED 1999 and ICCS 2009. It is a view that has evolved from ecological systems theories (Bronfenbrenner, 2004; Neal, \& Neal, 2013) and theories of situated cognition (Anderson, Greeno, Reder, \& Simon, 2000).

The field of civic and citizenship education includes cognitive aspects of learning as well as the development of attitudes towards aspects of civic life and dispositions to participate actively in the life of communities. One of the important contributions of the IEA studies investigating civic and citizenship education has been the emphasis on the role of cognitive skills in the preparation of young people to fulfill their roles as citizens. IEA studies of civic and citizenship education have recognized that, in order to participate effectively as citizens, young people need to possess a knowledge base and the capacity to reason about the institutions, events, actions and processes that exist in their civil and civic communities, as well as to develop and justify views and attitudes towards those things. In addition it recognizes that, as students come to know about and process cognitive aspects of civics and citizenship, they also develop and refine attitudes to, and dispositions to participate in, civic life. Conversely, as they develop interests in and a propensity to participate in aspects of civic life so they also learn and understand more about key aspects of civics and citizenship.

3 To describe cognitive and affective-behavioral content in general, we use the term "civics and citizenship" in this framework. However, for describing processes, concepts or domains we use "civic and citizenship" (without "s") in conjunction with the corresponding term or object (for example, the "civic and citizenship framework" or "civic and citizenship education").

(C) International Association for the Evaluation of Educational Achievement (IEA) 2016 


\subsubsection{The representation of civics and citizenship in the framework}

The ICCS 2016 Civic and Citizenship Framework is organized around four content domains:

- Content domain 1: Civic society and systems.

- Content domain 2: Civic principles.

- Content domain 3: Civic participation.

- Content domain 4: Civic identities.

Content domains describe areas of civics and citizenship about which individuals may have developed knowledge and understanding, and towards which they may also have developed perceptions and dispositions. Therefore, topics included in each content domain concern cognitive aspects (i.e. how much students know and understand), and perceptions (i.e. how students view them and are willing to act on them).

Cognitive processes may be viewed as (i) remembering or recalling information or processing content in terms of understanding, or (ii) applying an understanding to new situations (see Anderson, \& Krathwohl, 2001). Similar to the structure of cognitive domains in other IEA studies (see for example: Mullis, \& Martin, 2013), two following cognitive domains are identified in the ICCS 2016 framework:

- Cognitive domain 1: Knowing.

- Cognitive domain 2: Reasoning and applying.

This represents a change in terminology from ICCS 2009 for the Cognitive domain 2 due to the observation that the terms "reasoning" and "analyzing" were conceptually quite similar. Substituting "analyzing" with "applying" is proposed to indicate that students should be assessed with regard to their ability to make effective use of their civic knowledge in real world contexts.

Given the central importance of students' attitudes and dispositions to engage in society, the framework includes an affective-behavioral dimension that concerns the attitudes that students develop and their disposition to participate in the civic life of their societies (see Schulz, Losito, \& Kerr, 2011). The framework envisages this dimension as consisting of two major affective-behavioral domains that are identified in the ICCS assessment framework as:

- Affective-behavioral domain 1: Attitudes.

- Affective-behavioral domain 2: Engagement.

The two affective-behavioral domains attitudes and value beliefs described in the ICCS 2009 framework have been consolidated into affective-behavioral domain 1 in 2016. This was done to address concerns about whether the implicit distinction between more enduring and deeply-rooted attitudes from those that are more focused on specific issues and more time-specific was appropriate for adolescents in the age group under study. In the ICCS 2016 framework, the ICCS 2009 affective-behavioral domains behavioral intentions and behaviors were combined, together with dispositions related to civic participation such as interest or self-efficacy, which had been classified as attitudes in the previous study, into the affective-behavioral domain 2 (engagement). It needs to be recognized, however, that recent or past civic-related activities can also be regarded as contextual factors influencing learning outcomes. 


\subsubsection{Mapping assessment domains to the assessment instruments}

The ICCS assessment of the learning outcomes of civic and citizenship education comprises two types of instrument:

- A student test measuring cognitive representations and processes.

- Student questionnaires (international and regional) measuring affective-behavioral variables reflecting attitudes and engagement.

Data from the cognitive test will contribute to further elaboration of the proficiency scale of civic and citizenship knowledge established in ICCS 2009. The content of the scale is derived from the substance of the four content domains as operated on through the two cognitive domains.

Data from the international and regional student questionnaires will be used to articulate constructs pertaining to the two affective-behavioral domains and relating to the substance of the four content domains. The amount and type of assessment information accessed by each instrument will vary across the four content domains.

\subsection{Civic and citizenship content domains}

\subsubsection{Structures and key terms in the ICCS 2016 assessment framework}

\section{Structure of the content domains}

The four content domains of the ICCS 2016 assessment framework share the following structures:

- Sub-domain: This refers to a substantive or contextual component of a content domain. The sub-domains are described if they include sufficient discrete content to warrant individual definition and articulation. This model anticipates some overlap between the sub-domains within each domain.

- Aspect: This refers to specific content regarded as largely situated within a given subdomain.

- Key concept: This refers to concepts and processes common to sub-domains within a given content domain.

In short, each content domain is divided into sub-domains, and each sub-domain consists of one or more aspects. The key concepts can be expressed within the contexts of any of the sub-domains. Figure 2.1 illustrates the structure of the content domains in the ICCS 2016 assessment framework. 
Figure 2.1: The structure of the ICCS 2016 assessment framework content domains

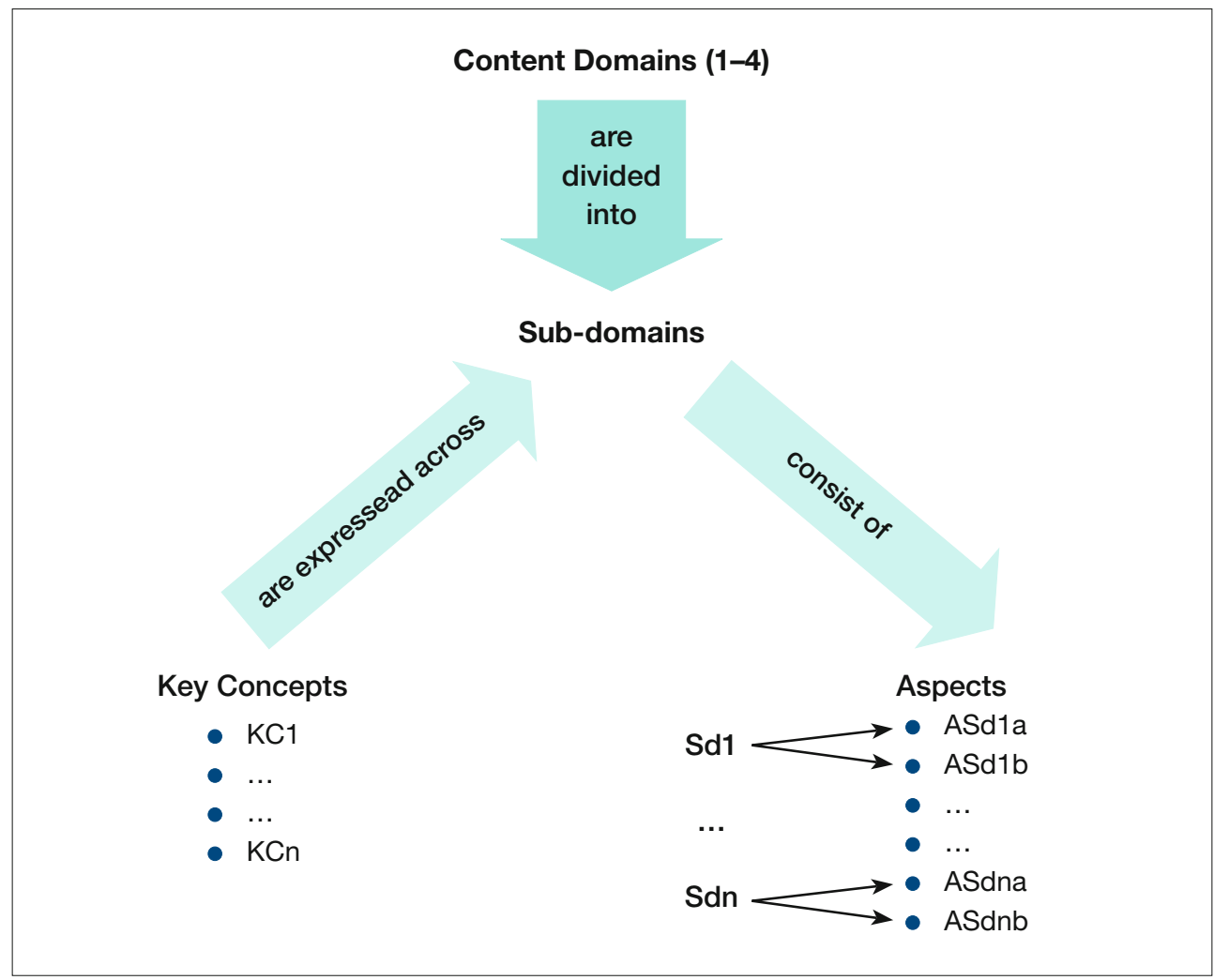

Note: $K C=$ Key concept; $S d=$ Sub-domain; $A S d=$ Aspect.

\section{Structure of the affective-behavioral domains}

The two affective-behavioral domains are described in terms of the types of student attitudes and engagement indicators relevant with respect to the civic and citizenship content domains.

\section{Structure of the cognitive domains}

The two cognitive domains are defined in terms of the cognitive processes that comprise them. This includes the assumption that processes are to be applied to content from within the four civic and citizenship content domains.

\section{Key terms}

The ICCS assessment framework frequently uses a set of key terms. The following definitions of these key terms are those used in this framework. The definitions of many of the terms used in the framework are the subject of ongoing and vigorous academic dialogue. The definitions of the key and domain-specific terms in this framework have been constructed to support consistent understandings of the framework's contents across the broad range of countries participating and interested in ICCS. 
Community A group of people who share something in common (for example, history, values, loyalties, a common goal). In this framework, community membership includes membership based on externally defined criteria relating to the function of the community (such as attending a school as a student) and membership defined by individuals' own belief of their membership (such as through identification with "like-minded" people regarding a political, religious, philosophical or social issue). ${ }^{4}$

Society A community defined by its geographical territory and within which the population shares a common culture (which may comprise and celebrate multiple and diverse ethnic or other communities) and way of life under conditions of relative autonomy, independence, and self-sufficiency.

Citizenship $\quad$ a. The legal status of being a citizen of a nation state or supranational legal community (for example the European Union).

b. The fact of individuals' participation, or lack of participation, in their communities. The term "citizenship," unlike the term "active citizenship," does not assume certain levels of participation.

Civil Refers to the sphere of society in which the shared connections between people are at a broader level than that of the extended family but do not include connections to the state.

Civic Refers to any community in which the shared connections between people are at a broader level than that of the extended family (including the state). Civic also refers to the principles, mechanisms, and processes of decisionmaking, participation, governance, and legislative control that exist in these communities.

\subsection{Civic and citizenship content domains}

The first content domain, civic society and systems, comprises the mechanisms, systems, and organizations that underpin societies. The second domain, civic principles, refers to the shared ethical foundations of civic societies. Civic participation deals with the nature of the processes and practices that define and mediate the participation of citizens in their civic communities (often referred to as active citizenship). The ICCS assessment framework recognizes the centrality of the individual citizen through the fourth content domain civic identities. This domain refers to the personal sense an individual has of being an agent of civic action with connections to multiple communities. Together, these four domains describe the civic and citizenship content to be assessed in ICCS.

\subsubsection{Content domain 1: Civic society and systems}

The content domain Civic society and systems focuses on the formal and informal mechanisms and organizations that underpin both the civic contracts that citizens have with their societies and the functioning of the societies themselves. The three subdomains of civic society and systems are:

- Citizens.

- State institutions

- Civil institutions.

4 Note that a community may still contain a level of diversity.

5 Note that "Global Citizenship" has been included as a concept in content domain 4 (civic identities). 


\section{Citizens}

The sub-domain Citizens focuses on the civic relationships between individuals and groups of citizens and their societies. The aspects of this sub-domain relate to knowledge and understanding of as well as beliefs about:

- Citizens' and groups' assigned and desired roles within their civic society

- Citizens' and groups' assigned and desired rights within their civic society

- Citizens' and groups' assigned and desired responsibilities within their civic society

- Citizens' and groups' opportunities and abilities to engage within their civic society.

\section{State institutions}

The sub-domain State institutions focuses on those institutions central to the processes and enacting of civic governance and legislation in the common interest of the people they represent and serve.

The aspects of this sub-domain are:

- Legislatures/parliaments

- Governments

- Economic structures, mechanisms and conditions

- Supranational/intergovernmental governance bodies

- Judiciaries

- Law enforcement bodies

- National defense forces

- Bureaucracies (civil or public services)

- Electoral commissions.

\section{Civil institutions}

The sub-domain Civil institutions focuses on those institutions that can mediate citizens' contact with their state institutions and allow citizens to actively pursue many of their roles in their societies.

The aspects of this sub-domain are:

- Companies/corporations

- Trade unions

- Political parties

- Non-governmental organizations (NGOs)

- Advocacy groups (for example, pressure, lobby, campaign, special interest groups)

- Traditional media (for example, newspaper, television and radio)

- New social media (for example, web forums, blogs, twitter, Facebook, and text messaging)

- Religious institutions

- Schools

- Cultural organizations. 


\section{Key concepts}
Power/authority Listed together as concepts dealing with the nature and consequences of the right or capacity of bodies or individuals to make binding decisions on behalf of others that these others are then required to accept and to adhere to.

Rules/law

Listed together as the explicit and implicit prescriptions for behavior. Rules are those prescriptions that are not required to be and are therefore not enforced by a sovereign body. Laws are considered to be those prescriptions that are enforced by a sovereign body.

Constitution The fundamental rules or laws of principle governing the politics of a nation or sub-national body.

Governance

The act and the processes of administering public policy and affairs.

Decision-making

The formal and informal processes by which decisions are made within and among civil and state institutions.

Negotiation The processes that underpin and are evident in negotiation, and the use and necessity of negotiation as a means of decision-making.

Accountability The requirement for representatives to answer to those they represent about the representatives' conduct of their duties and use of their powers. Accountability includes the assumption that representatives are able to accept responsibility for their failures and to take action to rectify them.

Democracy The ICCS assessment framework accepts the broadest definition of democracy "as rule by the people." This definition refers both to democracy as a system of governance and to the principles of freedom, equity, and sense of community ${ }^{6}$ that underpin democratic systems and guarantee respect for and promotion of human rights. Both representative democratic systems (such as national parliaments) and "direct democracy" systems (such as through referendums or systems used in some local community or school organizations) can be examined as democratic systems under the definition of democracy used in this framework.

Sovereignty The claim of each individual state/nation to have the ultimate power in making political decisions relevant to that state/nation and recognition that this power underpins the operation and viability of international organizations, agreements, and treaties.

Nation-building The process of developing among the people of a nation some form of a unified sense of national identity, with the aim of fostering long-term harmony and stability. Within the parameters of the ICCS assessment framework, nation-building is assumed to be a dynamic ongoing process in all nations rather than a process associated only with newly independent nations.

Statelessness The circumstances of people who do not have any legal bond of nationality or citizenship with any state. Included in this concept are the causes and consequences of statelessness. 


\begin{abstract}
Franchise/ Voting

The economy

The welfare state

Treaties

Sustainable development

Environmental sustainability

Globalization

Dissent

Listed together, these concepts refer to the rights, responsibilities, and expectations of people to vote in formal and informal settings. These concepts also refer, more broadly, to issues associated with voting and voting processes, such as compulsory and voluntary voting and secret ballots.

Systems governing the production, distribution, and consumption of goods and services within states, including industrial regulation, trade, taxation, and government spending including on social welfare. Economic conditions are both a focus of civic decisions as well as a key aspect of the environment in which decisions about other policies are made.

The role of a government in providing for the social and economic security of its people through support such as health care, pensions, and social welfare payments and benefits.

Binding agreements under international law entered into by eligible bodies such as states and international organizations.

Development that meets the needs of the present without compromising the ability of future generations to meet their own needs. Factors that can be considered in terms of sustainable development include environmental protection, economic development, social equality, and social justice.

A state in which demands placed on the natural world can be met without negatively impacting on the natural world or reducing its capacity to support human life.

The increasing international movement of commodities, money, information, and people; and the development of technology, organizations, legal systems, and infrastructures to allow this movement. The ICCS assessment framework acknowledges that a high level of international debate surrounds the definition, perceptions, and even the existence of globalization. Globalization has been included in the framework as a key concept for consideration by students. The definition is not a statement of belief about the existence or merits of globalization.

In democratic societies, dissent is a central notion that allows for voicing opposition to, expressing disagreement with, or standing apart from, the policies or decisions of the governing body.
\end{abstract}

\title{
2.3.2 Content domain 2: Civic principles
}

The content domain 'Civic principles' focuses on the shared ethical foundations of civic societies. The framework regards support, protection, and promotion of these principles as civic responsibilities and as frequently occurring motivations for civic participation by individuals and groups. The domain consists of four sub-domains:

- Equity

- Freedom

- Sense of community

- Rule of law. 


\section{Equity}

The sub-domain Equity focuses on the principle that all people have the right to fair and just treatment, and that protecting and promoting equity is essential to achieving peace, harmony, and productivity within and among communities. The principle of equity is derived from the notion of equality-that all people are born equal in terms of dignity and rights.

\section{Freedom}

The sub-domain Freedom focuses on the concept that all people should have freedom of belief, freedom of speech, freedom from fear, and freedom from want, as articulated in the United Nations Universal Declaration of Human Rights (United Nations, 1948). Societies have a responsibility to actively protect the freedom of their members and to support the protection of freedom in all communities, including those that are not their own.

\section{Sense of community}

The sub-domain Sense of community is related to the sense of belonging and connectedness within societies, and focuses on collective responsibility and common vision that exists amongst the individuals and communities within a society. When a strong sense of community exists individuals actively appreciate and acknowledge the diversity of individuals and communities that comprise a society as well as demonstrate responsibility toward its development. It is acknowledged (in regard to this subdomain) that manifestations of sense of community vary between societies, that there may be tensions within societies between demands for social cohesion and the existing diversity of views and actions, and that the resolution of these tensions is an ongoing area of debate within many societies.

\section{Rule of law}

The sub-domain Rule of law is related to the principle that all citizens, institutions and entities including the State itself are subject and accountable to laws, which are publicly promulgated, independently adjudicated, equally enforced and consistent with international standards and norms protecting human rights (United Nations, 1948). It requires recognition of the supremacy of law, the concept that all citizens are equal before the law regardless of their background and personal characteristics (such as gender, race, religion), fairness in the application of law, separation of powers, participation in decision-making, legal certainty, as well as legal and procedural transparency.

\section{Key concepts}

Concern for the The concept that the ultimate goal of civic and community action is to common good promote conditions that advantage all members of the community.

Human rights A form of inalienable entitlement of all human beings that, for the purpose of the ICCS assessment framework, is framed by the contents of the United Nations Universal Declaration of Human Rights (United Nations, 1948).

Empathy Intellectually or emotionally taking the role or perspective of others.

Social justice The distribution of advantage and disadvantage within communities. 


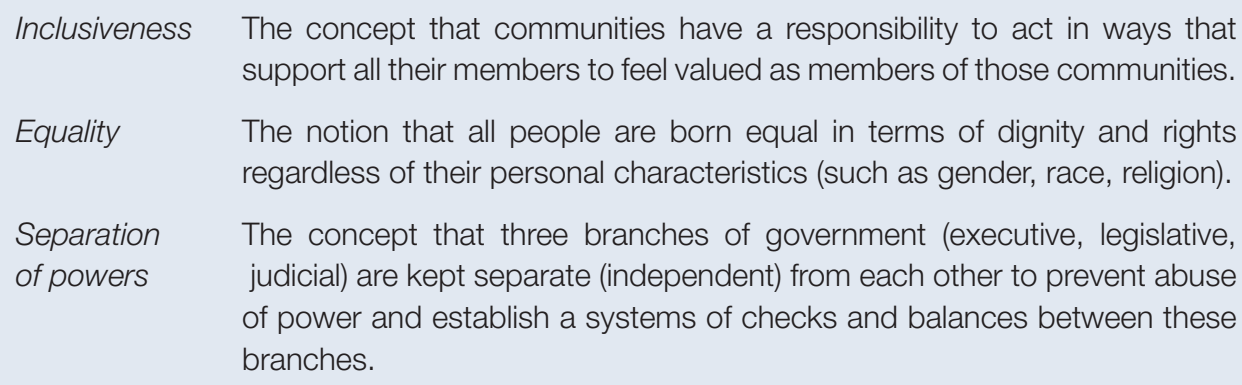

\subsubsection{Content domain 3: Civic participation}

The content domain Civic participation refers to the manifestations of individuals' actions in their communities. Civic participation can operate at any level of community and in any community context (including schools as the imminent context for the age group under study). The level of participation can range from awareness through engagement to influence. The three sub-domains of civic participation are:

- Decision-making

- Influencing

- Community participation.

\section{Decision-making}

The sub-domain Decision-making focuses on active participation that directly results in the implementation of policy or practice regarding the individual's community or a group within that community. The aspects of this sub-domain are:

- Engaging in organizational governance

- Voting.

\section{Influencing}

The sub-domain Influencing focuses on actions aimed at informing and affecting any or all of the policies, practices, and attitudes of others or groups of others in the individual's community. The aspects of this sub-domain are:

- Engaging in public debate (including participation through social media)

- Engaging in demonstrations of public support or protest (including "virtual" engagement through the use of, for example, online petitions)

- Engaging in policy development

- Developing proposals for action or advocacy

- Selective purchasing of products according to ethical beliefs about the way they were produced (ethical consumption/ethical consumerism)

- Recognizing corruption.

\section{Community participation}

The sub-domain Community participation focuses on participation, with a primary focus on enhancing a person's connections with a community, for the ultimate benefit of that community. The aspects of this sub-domain are: 
- Volunteering

- Participating in organizations

- Acquisition of information.

\section{Key concepts}

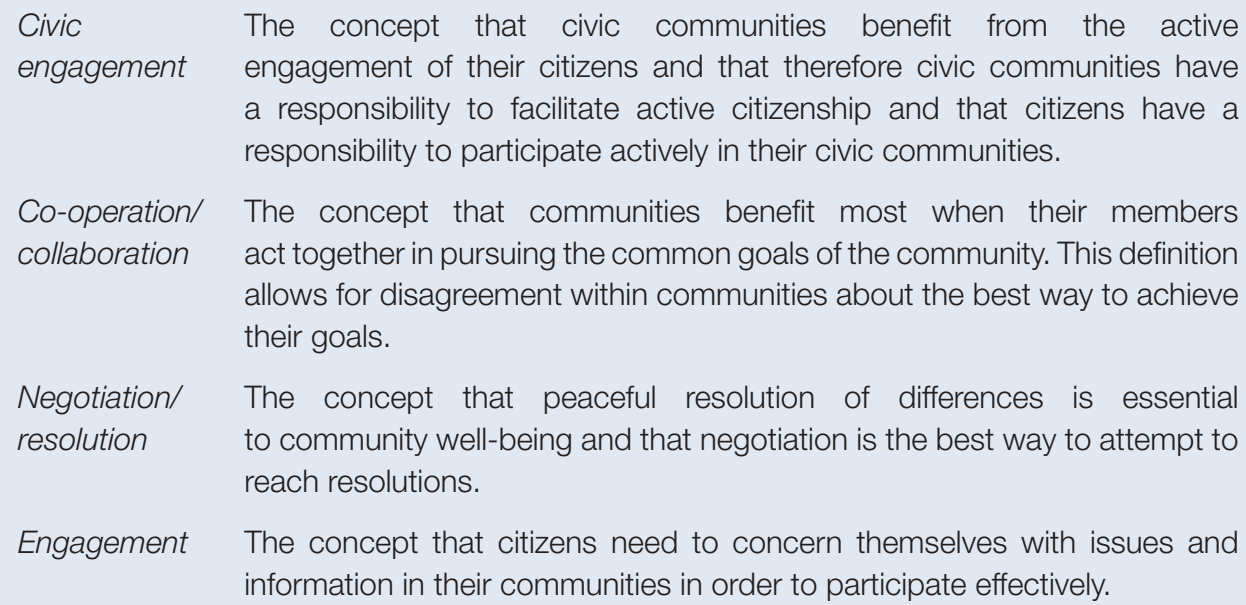

\subsubsection{Content domain 4: Civic identities}

The content domain Civic Identities includes the individual's civic roles and perceptions of these roles. As was the case with the conceptual model of CIVED, ICCS assumes that individuals both influence, and are influenced by, the relationships they have with family, peers, and civic communities. Thus, an individual's civic identity explicitly links to a range of personal and civic interrelationships. This framework asserts and assumes that individuals have multiple articulated identities rather than a single civic identity. Civic communities include points of reference at many levels ranging from family and local community to geographical regions or the global community.

Civic identities comprises two sub-domains:

- Civic self-image

- Civic connectedness.

\section{Civic self-image}

The sub-domain Civic self-image refers to the individual's experience of their place in each of their civic communities. Civic self-image focuses on the individual's civic and citizenship values and roles, the individual's understanding of and attitudes toward these values and roles, and the individual's management of these values and roles whether they are in harmony or in conflict within the individual.

\section{Civic connectedness}

The sub-domain Civic connectedness refers to the individual's sense of connection to their different civic communities and to the different civic roles the individual plays within each community. 
Civic connectedness also includes the individual's beliefs about and tolerance of the levels of diversity (of civic ideas and actions) within and across their communities, and their recognition and understanding of the effects of the range of civic and citizenship values and belief systems of their different communities on the members of those communities.

\section{Key concepts}

\begin{tabular}{|c|c|}
\hline $\begin{array}{l}\text { Civic } \\
\text { self-concept }\end{array}$ & $\begin{array}{l}\text { Individuals' view of themselves as citizens in their civic communities. } \\
\text { This view includes individuals' sense of the communities to which they } \\
\text { belong and their capacity to identify the nature and parameters of their civic } \\
\text { roles in their communities. }\end{array}$ \\
\hline Multiplicity & $\begin{array}{l}\text { Individuals' sense of the range of different roles and potentials they have } \\
\text { within and across their different communities. Included in this concept is the } \\
\text { understanding that an individual's roles and potentials are ever changing and } \\
\text { that these depend on the context of each separate community connection. }\end{array}$ \\
\hline Diversity & $\begin{array}{l}\text { Individuals' sense of and level of acceptance of the range of people and } \\
\text { viewpoints that exist within and across their communities. }\end{array}$ \\
\hline $\begin{array}{l}\text { Cultures/ } \\
\text { location }\end{array}$ & $\begin{array}{l}\text { Individuals' sense of the value and place of the cultures they associate } \\
\text { with their communities in their own civic lives and the civic lives of the other } \\
\text { members of their communities. }\end{array}$ \\
\hline Patriotism & $\begin{array}{l}\text { An individual's love for or devotion to their country (or countries), which can } \\
\text { lead to a willingness to act in support of that country (or countries). }\end{array}$ \\
\hline Nationalism & $\begin{array}{l}\text { The politicization of patriotism into principles or programs based on the } \\
\text { premise that national identity holds precedence over other social and } \\
\text { political principles. }\end{array}$ \\
\hline $\begin{array}{l}\text { Global } \\
\text { citizenship }\end{array}$ & $\begin{array}{l}\text { Individuals' sense of belonging to the global community and common } \\
\text { humanity that transcends local and national boundaries. }\end{array}$ \\
\hline $\begin{array}{l}\text { Civic and } \\
\text { citizenship } \\
\text { values }\end{array}$ & $\begin{array}{l}\text { Individuals' central ethical and moral beliefs about their civic communities } \\
\text { communities and their roles as citizens within their communities. }\end{array}$ \\
\hline
\end{tabular}

\subsection{Civic and citizenship cognitive domains}

Each of the four content domains encompasses different types of knowledge concerned with civics and citizenship (factual, procedural, conceptual and meta-cognitive) (Anderson, \& Krathwohl, 2001). The framework then considers the extent to which students develop the capacity to process the content of the four domains and reach conclusions that are broader than any single piece of knowledge. This includes the processes involved in understanding complex sets of factors influencing civic actions and planning for and evaluating strategic solutions and outcomes. It extends from direct applications of knowledge to reach conclusions about concrete situations through to the selection and assimilation of knowledge and understanding of multiple concepts in order to reach conclusions about complex, multifaceted, unfamiliar and abstract situations. This is a simplification of the hierarchy of cognitive processes articulated by Anderson and Krathwohl (2001): remembering or recalling information or processing content in terms of understanding or applying an understanding to new situations ${ }^{7}$.

7 The simplification is intended to reflect what is appropriate for students in the target grade and what is most relevant to civics and citizenship. 
Students' knowledge about civics and citizenship is measured by the ICCS cognitive test. To respond to the test items, students need to know the civic and citizenship content being assessed. Students also need to be able to apply more complex cognitive processing to their civic and citizenship knowledge and to relate their knowledge and understandings to real-world civic action.

The two ICCS cognitive domains summarize the cognitive processes that students are expected to demonstrate in the ICCS cognitive test. The data derived from the test items constructed to represent the processes in the cognitive domains will be used to construct a global scale of civic and citizenship knowledge and understandings of the four content domains. The first cognitive domain, knowing, outlines the types of civic and citizenship information that students are required to demonstrate knowledge of. The second domain, reasoning and applying, details the cognitive processes that students require to reach conclusions.

\subsubsection{Cognitive domain 1: Knowing}

Knowing refers to the learned civic and citizenship information that students use when engaging in the more complex cognitive tasks that help them make sense of their civic worlds. Students are expected to remember, recall or recognize definitions, descriptions, and the key properties of civic and citizenship concepts and content, and to illustrate these with examples. Because ICCS 2016 is an international study, the concrete and abstract concepts students are expected to know in the core cognitive assessment are those that can be generalized across societies.

\section{Processes}

$\begin{array}{ll}\text { Define } & \text { Identify statements that define civic and citizenship concepts and content. } \\ \text { Describe } & \begin{array}{l}\text { Identify statements that describe the key characteristics of civic and } \\ \text { citizenship concepts and content. }\end{array} \\ \text { Illustrate with } & \begin{array}{l}\text { Identify examples that support or clarify statements about civic and } \\ \text { examples }\end{array}\end{array}$

\subsubsection{Cognitive domain 2: Reasoning and applying}

Reasoning and applying refers to the ways in which students use civic and citizenship information to reach conclusions that are broader than the contents of any single concept and to make use of these in real-world contexts. Reasoning and applying includes, for example: the use of knowledge to reach conclusions about familiar concrete situations; the selection and assimilation of knowledge and understanding of multiple concepts; the evaluation of proposed and enacted courses of action; providing recommendations for solutions or courses of action.

\section{Processes}

Interpret Identify statements about information presented in textual, graphical, information and/or tabular form that make sense of the information in the light of a civic and citizenship concept.

Relate Use the key defining aspects of a civic and citizenship concept to explain or recognize how an example illustrates a concept. 


\begin{tabular}{ll} 
Justify & $\begin{array}{l}\text { Use evidence and civic and citizenship concepts to construct or recognize } \\
\text { a reasoned argument to support a point of view. }\end{array}$ \\
Integrate & $\begin{array}{l}\text { Identify connections between different concepts across themes and across } \\
\text { civic and citizenship content domains. }\end{array}$ \\
Generalize & $\begin{array}{l}\text { Identify civic and citizenship conceptual principles manifested as specific } \\
\text { examples and explain how these may apply in other civic and citizenship } \\
\text { contexts. }\end{array}$ \\
\hline Sugaluate & $\begin{array}{l}\text { Identify judgments about the advantages and disadvantages of alternative } \\
\text { points of view or approaches to civic and citizenship concepts and actions. }\end{array}$ \\
& $\begin{array}{l}\text { Identify courses of action or thought that can be used to alleviate } \\
\text { civic and citizenship problems expressed as conflict, tension, and/or }\end{array}$ \\
Predict & unresolved or contested ideas. \\
& Identify likely outcomes of given civic and citizenship policies strategies \\
& and/or actions.
\end{tabular}

\subsection{Civic and citizenship affective-behavioral domains}

Individuals may have developed beliefs, perceptions, dispositions, behavioral intentions and behaviors, which the ICCS 2016 framework conceptualizes as related to two affective-behavioral domains: attitudes and engagement. The ICCS student questionnaire includes items measuring the affective-behavioral domains that do not require correct or incorrect responses and are often measured through use of a Likerttype item format in the ICCS 2016 student questionnaires, indicating for example the extent to which respondents agree or disagree with a given statement. While most constructs or aspects are measured as part of the international student questionnaire, others are included as international options or in the regional student questionnaires for Europe and Latin America.

\subsubsection{Affective-behavioral domain 1: Attitudes}

The affective-behavioral domain Attitudes refers to judgments or evaluations regarding ideas, persons, objects, events, situations, and/or relationships. It is possible for individuals to harbor contradictory attitudes at the same time. Attitudes encompass responses that are focused on specifics and can change over time, as well as those reflecting broader and more fundamental (or deeply rooted) beliefs that tend to be constant over longer periods of time. ${ }^{8}$

The different types of attitude assessed in ICCS 2016 can be classified depending on their (primary) location in the four content domains:

- Students' attitudes toward civic society and systems

- Students' attitudes toward civic principles

- Students' attitudes toward civic participation

- Students' attitudes toward civic identities.

8 More enduring beliefs were conceptualized as "value beliefs" in the ICCS 2009 framework, as opposed to (less enduring and more changeable) "attitudes". However, they now form part of the same affective-behavioral domain in the ICCS 2016 assessment framework. 


\section{Students' attitudes toward civic society and systems}

The following constructs reflecting student attitudes toward civic society and systems will be measured using the international student questionnaire and the regional European and Latin American questionnaires in ICCS 2009:

- Students' perceptions of good citizenship

- Students' trust in institutions

- Students' perceptions of threats to the world's future

- Students' attitudes toward the influence of religion in society (international option)

- Students' perceptions of European future (European regional questionnaire)

- Students' attitudes toward European cooperation (European regional questionnaire)

- Students' attitudes toward the European Union (European regional questionnaire)

- Students' attitudes toward authoritarian government practices (Latin American regional questionnaire).

Students' perceptions of good citizenship: This construct refers to student beliefs regarding "good citizenship" and relates mainly to Content domain 1 (civic society and systems) but also to Content domain 2 (civic principles). Items asking about the importance of certain behaviors for "good citizenship" were included in the first IEA study on civic education in 1971 (Torney et al., 1975). In CIVED, a set of 15 items asked students to rate the importance of certain behaviors for being a good citizen (see Torney-Purta et al., 2001, p. 77f). Sub-scales concerned with conventional and with social-movementrelated citizenship were reported (see Schulz, 2004). Kennedy (2006) distinguished active (conventional and social-movement-related) from passive citizenship elements (national identity, patriotism, and loyalty). ICCS 2009 included 12 items on good citizenship behavior, most of which were similar to those used in CIVED and were used to form two scales on conventional and social-movement-related citizenship (Schulz et al., 2010b; Schulz, \& Friedman, 2011). For ICCS 2016 additional items will measure more passive forms of citizenship behavior.

Students' trust in institutions: This construct reflects students' feelings of trust in a variety of state and civic institutions in society, and relates mainly to Content domain 1 (civic society and systems). The first IEA civic education study included one item on trust in government (Torney et al., 1975). CIVED used a set of 12 items covering political/civic institutions, media, United Nations, schools, and people in general. ICCS 2009 used a similar range of 11 core items in a modified format together with three optional items on European institutions and state/provincial institutions. Across countries, results showed that students tended to express the lowest levels of trust in political parties and the highest levels of trust in courts of justice (Schulz et al., 2010b, pp. 103-109). In countries with relatively high scores on indices of corruption, and low scores on indices of government efficiency, more knowledgeable students expressed less trust in civic institutions, whereas positive correlations between civic knowledge and trust were recorded in countries with low indices of corruption (Lauglo, 2013). In ICCS 2016 student trust is measured with the same item set as in ICCS 2009, augmented by an item measuring trust in social media.

Students' perceptions of threats to the world's future: It has been reported that students express concern about global issues including those regarding poverty, hunger, wars, overpopulation and the environment (Holden 2007; Oscarsson, 1996; Rubin, 2002). 
In ICCS 2016, students are asked to rate the seriousness of a broad range of threats to key aspects of civilization such as the extent of poverty, living standards, human dignity, economic well-being, and environmental health indicating their personal level of concern. These aspects are also reflected in writings concerned with global education that envisages broadening student perspectives beyond national contexts (Burnouf, 2004; Hicks, 2003). Overall these ratings provide an indication of students' awareness of global issues and responses to individual items provide a perspective on profiles of concern.

Students' attitudes toward the influence of religion in society: Religion is often regarded as an important catalyst of civic participation (see Pancer, 2015; Putnam, \& Campbell, 2010; Verba, Schlozman, \& Brady, 1995). Smidt (1999) suggested that in the United States and Canada religious tradition and church attendance were associated with civil participation, even after controlling for the effects of other factors generally associated with civic participation. Similar findings have been reported for the United Kingdom (Storm, 2015). ICCS 2009 used a set of six items to assess students' attitudes toward religion. The set of items was part of an international option on religious denomination, practices, and attitudes toward the influence of religion in society. The results showed that in most countries students who attended religious services also held more positive attitudes towards the desirability of religious influence on society (Schulz et al., 2010b, pp. 107-113). ICCS 2016 includes a slightly modified set of questions regarding religion as an international option.

Students' perceptions of European future: Recent opinion surveys among European citizens have shown that majorities expect that their children's life will be more difficult than theirs, and that Europe's influence will be weakened in comparison with the influence of China or the United States (European Commission, 2014). The ICCS 2016 European regional questionnaire contains a new question with possible scenarios for the European future, asking students to rate the extent of their likelihood of occurring.

Students' attitudes toward European cooperation: Recent opinion polls have indicated that, in spite of a general surge in anti-European sentiment in some member countries, majorities among Europeans support decision-making about important issues at the European level (European Commission, 2014). In addition to this, results from Standard Eurobarometer survey showed that European citizens consider immigration as one of the major challenges that the EU is facing, and that it should be addressed through member states cooperation (European Commission, 2015). The European regional questionnaire in ICCS 2009 included a question measuring students' perception of harmonization in the European context, and results showed high levels of agreement with common European policies (Kerr et al., 2010). The European regional questionnaire includes a new question designed to measure students' endorsement of cooperation between European countries regarding a range of different issues.

Students' attitudes toward the European Union: Younger people have been reported to have a stronger identification with European citizenship than older age groups (European Commission, 2013). The European regional survey of ICCS 2009 showed that support for the establishment of centralized European institutions was not particularly strong, and that support for further enlargement varied considerably across participating countries (see Kerr et al., 2010). The European regional questionnaire for ICCS 2016 includes a question containing statements about the EU designed to measure students' attitudes toward this institution. 
Students' attitudes toward authoritarian government practices in Latin America: Surveys in the Latin American region have shown considerable support for authoritarian government practices among adults and adolescents, and that majorities among adult citizens supported non-democratic governments if they solved economic problems (United Nations Development Programme, 2004). Support for non-democratic government has been shown to be related to educational background, with more educated citizens being less supportive of authoritarian government practices (Cox, 2010). The Latin American regional questionnaire ICCS 2009 included items measuring the endorsement of authoritarian government practices and the justification of dictatorships (see Schulz, Ainley, Friedman, \& Lietz, 2011). Results showed that considerable proportions of lower secondary students in all participating countries showed support for non-democratic government practices, and that majorities saw dictatorships justified in case they provided economic benefits or more security. The Latin American regional questionnaire includes the same item set to measure students' attitudes toward authoritarian government practices and justification for dictatorships.

\section{Students' attitudes toward civic principles}

The following constructs reflecting student attitudes toward civic principles are measured as part of the international student questionnaire, the regional European and the Latin American regional questionnaires in ICCS 2016:

- Students' attitudes towards democratic values

- Students' attitudes toward gender rights

- Students' attitudes toward equal rights for all ethnic/racial groups

- Students' attitudes toward equal rights for immigrants (European regional questionnaires)

- Students' perception of discrimination in European societies (European regional questionnaire)

- Students'views on age limitations for young people (European regional questionnaire)

- Students' perception of discrimination of minorities in Latin American societies (Latin American regional questionnaire)

- Students' attitudes toward disobedience to the law (Latin American regional questionnaire)

- Students' sense of empathy (Latin American regional questionnaire)

- Students' attitudes toward homosexuality (Latin American regional questionnaire).

Students' perceptions of democracy: This construct refers to student beliefs about democracy and relates mainly to Content domain 2 (civic principles). In the IEA CIVED survey, students were asked to rate a number of characteristics of society as either "good or bad for democracy" (see Torney-Purta et al., 2001). ICCS 2009 used a set of nine items that measured the extent of student agreement as to what a society should be like using a set of items that were adapted from a subset of those included in CIVED. In addition, three items measured students' beliefs about what should be done in response to groups that pose threats to national security. Most of these items were endorsed by very large majorities of students across all participating countries (Schulz et al., 2010b). In ICCS 2016, students' attitudes toward democratic values are assessed using a different format that requires students to rate a number of possible characteristics of a society as "good", "bad" or "neither good nor bad" for democracy. 
Students' attitudes toward gender rights: This construct reflects student beliefs about rights for different gender groups in society. The first IEA civic education study in 1971 included four items measuring support for women's political rights. The CIVED survey used a set of six items to capture students' attitudes regarding women's political rights (Torney-Purta et al., 2001). ICCS included seven items on gender rights, some of them identical with or similar to those used in CIVED. The results showed large majorities agreeing with the positive and disagreeing with negative statements about gender equity; female students expressed more support for gender equity than males (Schulz et al., 2010b, pp. 95-98). The ICCS 2016 student questionnaire includes the same set of seven items to measure student attitudes toward gender equality.

Students' attitudes toward equal rights for all ethnic/racial groups: This construct reflects students' beliefs about equal rights for all ethnic/racial groups in a country. CIVED measured this construct with four items, while ICCS 2009 used five statements to derive a scale reflecting attitudes toward equal rights for all ethnic/racial groups (Schulz et al., 2010b; Torney-Purta et al., 2001). ICCS 2016 uses the same set of items to measure this construct.

Students' attitudes toward the rights of immigrants in European societies: This construct reflects students' beliefs about rights for immigrants. CIVED measured this construct with eight items, five of which were included in a scale reflecting attitudes toward immigrants (Schulz, 2004; Torney-Purta et al., 2001). ICCS 2009 included a slightly modified version of the same five items used for scaling, together with one additional item. In ICCS 2009, students tended to be overwhelmingly in favor of equal rights for immigrants with female students being more supportive than males (Schulz et al., 2010b, pp. 99-102). Results from the European Social Survey among adults suggest that public attitudes towards immigration are closely linked to people's educational background (Masso, 2009; Paas, \& Halapuu, 2012). Some studies show an increase in anti-immigrant attitudes among European youth (Rustenbach, 2010) and, even though no systematic data have yet been collected on this issue, further growth in refugee intake from the Middle East may have resulted in further changes. ${ }^{9}$ The regional European questionnaire in ICCS 2016 uses the same set of items to measure students' attitudes toward rights of immigrants in their country of residence.

Students' views on age limitations for young people in European societies: Legal age limits for rights to undertake different activities vary considerably across countries, even within the context of Europe. While the minimum voting age (in particular for local elections) has been lowered in some European countries, in most countries young people can only vote once they are 18 . There are also many differences across European countries with regard to the required minimum age for buying alcohol; adult surveys have shown majorities across European countries supporting 18 as the legal age limit for the acquisition of alcohol (European Commission, 2010). The European regional questionnaire includes a question asking students to choose between different legal age limits that they prefer for a number of different behaviors, including buying alcohol, voting, and driving licenses.

9 It should be noted that perceptions of refugees and immigration may differ, for example, people with positive attitudes toward immigration in general may have less favorable views about accepting refugees and vice versa. The recent growth in the numbers of refugees in many European countries is not reflected in the development of the ICCS 2016 study and the instruments do not address this distinction. 
Students' attitudes towards freedom of movement for European citizens within Europe: Freedom of movement for European citizens across EU member countries was an essential part of the Lisbon Strategy (Bongardt, \& Torres, 2012). A recent survey of adults within Europe showed that just under half of all respondents were worried about immigration from within the European Union (German Marshall Fund, 2014). EU member countries tend to have the highest share of free-movement flows in total permanent migration movements (OECD, 2012). A high degree of free movement of workers is also found in the member countries of the European Economic Area (EEA), Iceland, Liechtenstein, and Norway (Alsos, \& Eldring, 2008; Dølvik, \& Eldring, 2008). Main challenges to the principle of free movement of persons involve a disproportionate monitoring and surveillance of movement of all individuals, together with other hidden, as well as visible barriers to make movement and residence more inclusive (Carrera, 2005). The European regional questionnaire in ICCS 2009 included a set of items measuring students' perceptions regarding the freedom of movement between EU countries for European citizens, which were used to derive two constructs, one reflecting support freedom of movement, and the other preferences for restrictions. ICCS 2009 results showed student recognition of the benefits of free movement, but also large proportions in favor of restricting the movement of workers across borders (see Kerr, Sturman, Schulz, \& Burge, 2010, pp. 94-98). This principle may come into greater prominence in public discussions with the advent of large numbers of refugees and displaced people moving to and across Europe. The ICCS 2016 European regional questionnaire includes a modified set of six items measuring students' attitudes toward freedom of movement.

Students' perceptions of discrimination in European societies: Eurobarometer surveys among adults have shown that people perceive quite high levels of discrimination across European countries, in particular with regard to the ethnic origin of individuals (European Commission, 2012a). It has been suggested that people from European countries with more effective antidiscrimination laws are more knowledgeable about rights regarding discrimination (Ziller, 2014). The ICCS 2016 European regional questionnaire includes a new question presenting students with a number of statements about discrimination, for which they should rate their agreement or disagreement.

Students' perceptions of discrimination in Latin American societies: Opinion surveys among adults across Latin American countries have shown that poor people were perceived as suffering most from discrimination, followed by indigenous and afrodescendants (Chong, \& Ñopo, 2007; Nopo, Chong, \& Moro, 2010) and that perceptions of discrimination were influenced by individuals' background (skin color and ethnicity), as well as contextual factors (Canache, Hayes, Mondak, \& Seligson, 2014). The ICCS 2016 regional questionnaire for Latin America includes a set of items measuring the extent to which students perceive social groups as discriminated in their countries.

Students' attitudes toward disobedience to the law in Latin America: Cross-national adult surveys in the Latin American countries have shown a high level of ambiguity with regard to civic morality (i.e. moral behavior and acceptance of disobedience to the law), with some countries of the region recording high proportions of acceptance of law-breaking (Letki, 2006), which were particular high among young people (Torgler, \& Valev, 2004). The Latin American regional questionnaire of ICCS 2009 included a set of items measuring students' acceptance of breaking the law under different 
circumstances, and results showed that larger proportions of young people in the participating countries endorsed disobediences to the law, in particular in cases where it was perceived as the only way to achieve things, help the family, or when it was done without bad intentions. The regional questionnaire for participating Latin American countries in ICCS 2016 includes the same item set as in the previous survey, which will allow comparisons over time.

Students' sense of empathy in Latin America: A sense of empathy relates to the disposition of an individual to enter someone else's world without being influenced by their own views and values (Rogers, 1975). Distinctions are made between affective and emotional components (Eisenberg, 1995; Strayer, 1987), and cognitive processes that allow people to imagine assuming other people's roles (Piaget, 1965). A sense of emotional empathy is viewed as motivating help for others and indicating compassion and concern for other human beings (Hoffman, 1981). The Latin American regional questionnaire of ICCS 2009 included a question that asked students to rate their level of concerns when observing suffering of classmates in different situations. The results showed that females tended to express higher levels of empathy than males (Schulz, Ainley, Friedman, \& Lietz, 2011). The Latin American regional questionnaire for ICCS 2016 includes the same items as in the previous survey with on additional item designed to measure students' sense of empathy.

Students' attitudes toward homosexuality in Latin America: Survey data from the Latin American region suggest considerable differences across countries and a divided public opinion with regard to attitudes toward homosexuality in the region. For example, results from the Latinobarometer show, as a whole, people from the region did not feel homosexuality was justified and did not support same sex marriage, although considerable country differences were observed (Latinobarómetro, 2009). Attitudes towards homosexuality in the region are often influenced by age, gender, education, and religious beliefs (Kelley, 2001; Pew Research Center, 2014). In ICCS 2009, the Latin American regional questionnaire asked students to rate their agreement with a set of positive and negative statements about homosexuality, which did not form a reliable scale. In accordance with previous survey research among adults, the results showed considerable variation in attitudes across the participating countries, with majorities of students in Chile and Mexico supporting the legalization of gay marriage (Schulz, Ainley, Friedman, \& Lietz, 2011). The regional instrument for Latin America in ICCS 2016 includes a modified set of items measuring students' attitudes toward homosexuality.

\section{Students' attitudes toward civic participation}

The international and regional questionnaires for Europe and Latin American in ICCS 2016 include measures regarding the following attitudes related to civic participation:

- Students' assessment of the value of student participation at school

- Students' attitudes toward political consumerism (European regional questionnaire)

- Students' attitudes toward corrupt practices (Latin American regional questionnaire)

- Students' attitudes toward violence (Latin American regional questionnaire).

Students' assessment of the value of student participation at school: This construct reflects students' beliefs regarding the usefulness of participating in civic-related activities at school and is as such closely related to the more general concept of political efficacy. Adolescents are generally unable to vote or run for office in "adult politics," but they 
experiment as students to determine what degree of power they have to influence the ways schools are run (Bandura, 1997, p. 491). CIVED included seven items asking about students' perceptions of their influence at school. Four of these questions focused on general confidence in school participation (Torney-Purta et al., 2001). ICCS 2009 used a set of four (partly modified) CIVED items and one additional item reflecting student attitudes toward the value of student participation in civic-related activities at school. Most students across participating countries valued student participation at school, and females tended to be more supportive than male students (Schulz et al., 2010b). ICCS 2016 uses a set of five items (including four from the previous survey) to measure students' attitudes toward participation in school activities.

Students' attitudes toward political consumerism in Europe: Over the past 20 years, political or ethical consumerism has emerged as an important part of citizenship engagement; this refers to the buying or boycotting of products or services for political or ethical reasons (Micheletti, \& Stolle, 2004; Stolle, Hoghe, \& Micheletti, 2005). Political consumerism is defined as the choice of producers and products with the intention of changing institutional or market practices (Micheletti, \& Stolle, 2015). The ICCS 2016 European regional questionnaire includes a question asking students to rate their agreement or disagreement with several statements about political or ethical consumerism.

Students' attitudes toward corrupt practices in Latin America: Corruption is widely regarded as one of Latin America's most salient problems and, with few exceptions, countries in this region tend to have low indices of transparency in cross-national surveys (Transparency International, 2014). Citizens' perceptions of the level of corruption have also been found to be related to lower levels of trust in institutions (Morris, \& Klesner, 2010). Furthermore, large proportions of Latin American citizens reported in regional surveys direct experiences with corrupt practices (Morris, \& Blake, 2010) and the World Values Survey found that in this region acceptance of corruption was relatively higher than in other countries (Torgler, \& Valev, 2004). In its Latin American regional questionnaire, ICCS 2009 gathered data about young people's attitudes toward corrupt practices, and results showed an acceptance of corrupt practices by many, albeit not a majority of students (Schulz, Ainley, Friedman, \& Lietz, 2011). The ICCS 2016 Latin American regional questionnaire includes the same question as in the previous survey, and will allow changes in attitudes since 2009 to be monitored.

Students' attitudes toward violence in Latin America: Among the pressing problems that Latin American societies are facing, violence and crime are those with wide-reaching consequences for young people's socialization into society (Reimers, 2007). Exposure to violence has been identified as causing higher levels of aggressive and violent behavior among young people (Chaux, 2009; Chaux, \& Velázquez, 2009). Young people with supportive attitudes towards violence are more likely to participate in violent behavior themselves (Copeland-Linder, Johnson, Haynie, Chung, \& Cheng, 2012). The ICCS 2009 Latin American questionnaire asked students to rate their agreement or disagreement with a series of statements about the use of violence. While most students rejected positive statements about the use of violence, males tended to be more supportive of violence than females (Schulz, Ainley, Friedman, \& Lietz, 2011). In the Latin American regional questionnaire for ICCS 2016, students are presented with the question augmented by two further new items designed to measure students' attitudes toward the use of violence. 


\section{Students' attitudes toward civic identities}

The following constructs reflecting student attitudes toward civic identities were measured as part of the international student questionnaire or the European and Latin American regional questionnaires in ICCS 2009:

- Students' attitudes toward their country of residence

- Students' sense of European identity (European regional questionnaire)

- Students' perceptions of their own individual future (European regional questionnaire)

- Students' acceptance of diversity (Latin American regional questionnaire).

Students' attitudes toward their country of residence: This construct reflects students' attitudes toward abstract concepts of nation. Various forms of national attachment may be distinguished (symbolic, constructive, uncritical patriotism, or nationalism), which differ from feelings of national identity (Huddy, \& Khatib, 2007). Kennedy (2010) argued that students in Hong Kong viewed citizenship as involving legal obligations to authorities, personal obligations to support others, and patriotic obligations to support the nation state. The CIVED survey included 12 items reflecting attitudes toward the students' country. Four of these items were used to measure a construct called positive attitudes toward one's nation (Torney-Purta et al., 2001) while another set of four items reflected protective nationalism (Barber, Fennelly, \& Torney-Purta, 2013). ICCS 2009 used a set of eight items (four of them from CIVED) to measure students' attitudes toward the country they live in. The results showed that large majorities across participating countries endorsed positive statements about their countries of residence; however, notable differences were recorded between young people with and without immigrant backgrounds (Schulz et al., 2010b, pp. 101-104). ICCS 2016 assesses attitudes toward their country (of residence) using a slightly reduced set of items measuring students' attitudes toward their country of residence.

Students' sense of European identity: European identity and its citizens' sense of belonging have been important themes of debate over the past decade within the EU (Alnæs, 2013; Checkel, \& Katzenstein, 2009; European Commission, 2012b; Delanty 1995, 2006; Delanty, \& Rumford, 2005; Duchesne, 2008; Herrmann, Risse, \& Brewer, 2004; Karolewski, \& Kaina, 2006, 2013; Pichler, 2008; Spannring, Wallace, \& Datler, 2008). The establishment of European institutions and integration of EU member countries, and in particular the signing of the Treaty on the European Union (better known as the Treaty of Maastricht), have had consequences for the concept of European identity and citizenship (Osler, \& Starkey, 2008). While some scholars claim that supra-national identities have superseded national identities (see for example, Osler, \& Starkey, 2001, 2008; Soysal, 1994), others hold that notions of national citizenship still remain dominant (Delanty, 2007; Fligstein, 2009). The European regional questionnaire of ICCS 2009 included a question about the extent to which lower-secondary students have developed a sense of European identity. Results showed that, while most students regarded themselves as Europeans, relatively few students viewed their European identity as more important than their national identity (Kerr et al., 2010). The European regional questionnaire for ICCS 2016 includes the same question as in the previous survey in order to measure changes in the sense of European identity over time. 
Students' perceptions of their own individual future in European societies: In a previous part of the framework, we drew attention to the need to examine perceptions of the future held by students. There is a body of literature concerned with the measurement of beliefs about, and perceptions of the future or future time perspectives (Husman, \& Shell, 2008). This measurement goes beyond simple measures of dispositional optimism and pessimism (Lemola, Raikkonen, Mathews, Schier, Heinonen, Pesonen, \& Lahti, 2010). Examining perceptions of the future involve an element of appraisal, as well as a response to that appraisal. We have already noted the evidence that adults in European countries think that life for the next generation will be more difficult that it was for themselves (European Commission, 2014). The ICCS 2016 European regional questionnaire asks students about the likelihood of finding employment and better financial conditions in the future.

Students' acceptance of diversity in Latin America: Acceptance of minority groups and the rejection of discrimination can be viewed as essential for ensuring the well-being for all members of society, as well as an educational goal (Cabrera, Nora, Terenzini, Pascarella, \& Hagedorn, 1999; Cote, \& Erikson, 2009; Morley, 2003). An example of the integration of this educational aim for civic and citizenship education is the Colombian program Citizenship Competencies, which encompasses learning about pluralism, identity, and respect for diversity, as well as issues related to exclusion and discrimination (Chaux, Lleras, \& Velázquez, 2004; Ministry of Education of Colombia, 2004). The ICCS 2009 Latin American questionnaire included a set of items measuring the acceptance of different social minority groups as neighbors. While most students across the six participating countries were tolerant of people with different nationality, from other regions of the country, or with a different skin color, fewer students approved of people with a different sexual orientation in their neighborhood (Schulz, Ainley, Friedman, \& Lietz, 2011). Acceptance of social minority groups tended be positively associated with civic knowledge, and had negative correlations with authoritarian attitudes (Caro, \& Schulz, 2012). The Latin American regional questionnaire for ICCS 2016 includes a modified set of items measuring students' acceptance of social minorities in their neighborhood.

\subsubsection{Affective-behavioral domain 2: Engagement}

The affective-behavioral domain Engagement refers to students' civic engagement, students' expectations of future action, and their dispositions to actively engage in society (interest, sense of efficacy). This affective-behavioral domain, assessed in the student perceptions questionnaire, requires items that ask students about their intentions toward civic action in the near future or when they are adults, as well as items measuring the extent to which students are interested and feel competent to engage. Given the age group to be surveyed in ICCS 2016 and the limitations that adolescents face in participating as active citizens, students' dispositions towards engagement are of particular importance when collecting data about active citizenship. In addition to active involvement in those civic forms open to this age group (such as school-based activities, youth organizations, or community groups), young people may now become involved in virtual networks through new social media. These relatively new forms of engagement are considered more explicitly in ICCS 2016. 
While indicators of engagement are mainly related to the content domain civic participation, they are also concerned with other content domains (mainly at the level of individual items). For example, a student's expected membership in a political party is related to the content domain civic society and systems, a student's expected engagement in political consumerism to the content domain civic principles, and a students' participation in a group to help the local community to civic identity.

One important aspect of measuring dispositions toward civic engagement in the area of civics and citizenship, which has traditionally been a central focus in political science research, is political participation. It can be defined as "activity that has the intent or effect of influencing government action-either directly by affecting the making of implementation of public policy or indirectly by influencing the selection of people who make those policies" (Verba et al., 1995, p. 38). Putnam (1993, p. 665) regarded civic engagement more broadly as "people's connections with the life of their communities, not merely politics."

Verba et al. (1995) identified the following three factors as predictors of political participation: (i) Resources enabling individuals to participate (time, knowledge); (ii) psychological engagement (interest, efficacy); and (iii) "recruitment networks," which help to bring individuals into politics (these networks include social movements, church, groups, and political parties). Inequality in citizens' opportunities for political participation has been raised as an issue for democracy, in particular in the United States (see for example Schlozman, Verba, \& Brady, 2012). There is a general consensus regarding the importance of formal education in influencing the extent of adult engagement in society (see Nie, Junn, \& Stehlik-Barry, 1996; Pancer, 2015).

During the 1970s and 1980s, protest behavior as a form of participation became more prominent in Western democracies (Barnes, \& Kaase, 1979). Scholars have distinguished "conventional" (voting, running for office) from "unconventional (social movement)" activities (grass-root campaigns, protest activities). They have also distinguished among the latter legal from illegal forms of behavior (Kaase, 1990). In view of the rapid expansion of new types of political activities, Van Deth (2014) proposed a classification of political participation, which, in addition to conventional and unconventional types of engagement, also included problem- or community-oriented forms of participation and individualized and creative modes of participation.

According to Ekman and Amnå (2012), it is necessary to distinguish civic participation (latent political participation) from manifest political participation, as well as individual forms from collective forms of engagement. Ekman and Amnå distinguished forms of latent involvement (such as interest and attentiveness) from more active forms of engagement (defined as either individual or collective activities). With regard to political passivity, which has been observed as a growing phenomenon especially among young people, it is important to distinguish unengaged from disillusioned citizens (Amnå, \& Ekman, 2014). While unengaged passive citizens are still keeping themselves informed and are willing to consider civic engagement if needed, disillusioned passive citizens have lost faith in the possibility of influencing and have become alienated. Therefore, in addition to active engagement, basic dispositions toward engagement (interest or self-efficacy) and behavioral intentions (underlying preparedness to take action) are of crucial importance when studying young people's engagement. 
In recognition of the above, and also in view of the fact that young people at age of 1315 years are limited with respect to the extent in which they can participate in society, indicators of engagement are conceptualized according to the following typology:

- Dispositions

- Behavioral intentions

- Civic participation.

\section{Dispositions}

With regard to students' dispositions toward civic engagement, ICCS 2016 will distinguish the following dispositions toward engagement:

- Students' interest in political and social issues

- Students' sense of citizenship self-efficacy.

Students' interest in political and social issues: The first IEA Civic Education Study in 1971 included measures of interest in public affairs television, which turned out to be a positive predictor of civic knowledge and participation (Torney et al., 1975). An item on political interest was used in the CIVED survey (Torney-Purta et al., 2001). Similar to earlier findings, CIVED results also showed interest in politics as a positive predictor of civic knowledge and likelihood to vote (Amadeo et al., 2002). ICCS 2009 used a list of items covering students' interest in a broader range of six different political and social issues, including an optional item referring to interest in European politics. The results showed that students tended to have considerable interest in social and also political issues in their own countries, but were less interested in international politics (Schulz et al., 2010b). ICCS 2016 will assess students' interest using an additional item about their interest in political and social issues, in conjunction with a question about their parents' interest in these issues.

Students' sense of citizenship self-efficacy: This construct reflects students' self-confidence in active citizenship behavior. Individuals' "judgments of their capabilities to organize and execute courses of action required to attain designated types of performances" (Bandura, 1986, p. 391) are deemed to have a strong influence on individual choices, efforts, perseverance, and emotions related to the tasks. The concept of self-efficacy constitutes an important element of Bandura's social cognitive theory about the learning process, in which learners direct their own learning (Bandura, 1993). The distinction between self-concept regarding political participation (political internal efficacy) and citizenship self-efficacy is that: whereas internal political efficacy asks about global statements regarding students' general capacity to act politically, citizenship selfefficacy asks about the students' self-confidence to undertake specific tasks in the area of civic participation. ICCS 2009 included seven items reflecting different activities that were relevant for students of this age group, which are also included in the ICCS 2016 student questionnaire.

\section{Behavioral intentions}

ICCS 2016 will distinguish between the following three types of behavioral intentions:

- Expectations to participate in legal and illegal forms of civic action in support of or protest against important issues

- Expectations of political participation as adults

- Expectations of participating in future school-based activities. 
Students' expectations to participate in forms of civic action: In ICCS 2009 a set of nine items reflected students' expectations for future involvement in protest activities (for example, collecting petitions, participating in protest marches, blocking traffic). The items related to two different dimensions of protest behavior: legal and illegal. In ICCS 2016 items measure forms of civic action, including those in protest against and in support of particular issues, using a similar set of items. The items include actions in support of environmental sustainability, as well as use of new social media.

Students' expectations of political participation as adults: Young people who intend to participate in political activities have been shown to be much more likely to actually participate at a later point in time (Eckstein, Noack, \& Gniewosz, 2013). In ICCS 2009 these types of behavioral intentions were measured with set of nine items (two of which were optional for countries), which was used to measure two different constructs (expected electoral participation and expected participation in political activities). While majorities of students across participating countries expected to participate in elections, relatively few students expressed intentions to engage in more active forms of political participation (Schulz et al., 2010b, pp. 143-146). The ICCS 2016 student questionnaire includes the same set of ICCS 2009 items, augmented by a number of items measuring more informal ways of citizen participation in society (including one new item regarding personal efforts to help the environment).

Students' expectations of participating in future school-based activities: The theory of planned behavior links attitudes to behaviors through intentions (Ajzen, 2001; Ajzen, \& Fishbein, 2000). This theory posits that attitudes influence actions through reasoned processes (that are manifested as intentions). For example, intentions formed relatively early in secondary school are powerful predictors of subsequent participation in education (Khoo, \& Ainley, 2005). More specifically related to citizenship, Keating and Janmaat (2015) reported analyses of longitudinal data in the United Kingdom, and suggested that participation in school-based political activities has a positive influence on future electoral and political engagement. A set of items measuring this construct were developed for ICCS 2016 to reflect students' beliefs about their expectation of undertaking future civic activities within the school context (for example, voting in school elections or engaging in a public debate about school-related issues).

\section{Civic participation}

Students at the age group under study in ICCS are not yet old enough to have access to many forms of citizenship participation in society. However, there is evidence of links between youth participation and later engagement as adult citizens (see for example, Verba et al., 1995). Furthermore, having been part of civic-related activities at school has been suggested as factor influencing future citizenship engagement (Pancer 2015; Putnam, 2000). In view of the latter, it needs to be acknowledged that current or past involvement in youth groups, school governance or campaigns may play a role as contextual factor in determining civic-related learning outcomes.

ICCS 2016 includes measures of the following types of more active students' civic engagement:

- Students' engagement with social media

- Students' engagement in organizations and groups (outside of school)

- Students' engagement in school activities. 
Students' civic participation through social media: The importance of social media has risen exponentially over the past years (Banaji, \& Buckingham, 2013; Mihailidis, 2011; Rainie, Smith, Schlozman, Brady, \& Verba, 2012; Segerberg, \& Bennett, 2011) and research suggests a potential enhancement of civic participation among people when content is interactive (for example, via chat rooms or message boards) instead of the one-way communication of more traditional media (Bachen et al., 2008; Kahne et al., 2011). The ICCS 2016 student questionnaire includes three new items that measure the extent to which students engage with political and social issues via social media.

Students' civic participation in the organizations and groups: Citizens' involvement in organizations and groups can be seen as a clear indicator of civic engagement (Putnam, 2000; Van Deth, Maraffi, Newton, \& Whiteley, 1999). However, it can also be regarded as a resource for future engagement (Putnam, 1993). The ICCS 2009 student questionnaire asked students about their current or past participation in organizations in their communities, such as human-rights groups, religious associations, and/or youth clubs. Similar to the findings of the CIVED study in 1999 (Amadeo et al., 2002; Torney-Purta et al., 2001), ICCS 2009 results showed that only minorities among students reported to have participated in these organizations or groups (Schulz et al., 2010b, pp. 129-134). ICCS 2016 assesses students' participation in the community with a slightly modified set of 10 items (including three optional items).

Students' civic participation in school activities: Numerous scholars have underlined the importance of students' experience at school for developing a sense of having power to influence matters in the community (Bandura, 1997). Research has provided evidence that more democratic forms of school governance can contribute to higher levels of political engagement (see for example Mosher, Kenny, \& Garrod, 1994; Pasek, Feldman, Romer, \& Jamieson, 2008). The ICCS 2009 student questionnaire asked students about a wide range of civic-related participation at school (for example, in school councils/ parliaments, or in student debates). The results showed that majorities of students reported to have participated in many of these activities in school, and that there were positive associations with civic knowledge and engagement (Schulz et al., 2010b). ICCS 2016 assesses students' participation at school with a slightly modified set of eight items (including one optional item).

\subsection{Mapping items to domains}

The content domains relate to both cognitive and affective-behavioral domains. Any item that measures one of the two cognitive domains can be mapped to any of the four content domains. The same is true for items measuring any of the affective-behavioral constructs. Table 2.1 shows how items can be placed in different cells and mapped to either cognitive or affective-behavioral domains, as well as to content domains.

Cognitive items from both domains (knowing and reasoning and applying) and affectivebehavioral items from two domains (attitudes and engagement) were developed in the contexts of all four content domains. Because these mappings are guided by the compatibility of each content domain to the different affective-behavioral and cognitive domains, they do not necessarily spread evenly across the content domains. 
Table 2.1: Relationship between cognitive or affective-behavioral and content domains

\begin{tabular}{|c|c|c|c|c|}
\hline & $\begin{array}{c}\text { Content } \\
\text { domain 1: } \\
\text { Civic society } \\
\text { and systems }\end{array}$ & $\begin{array}{c}\text { Content } \\
\text { domain 2: } \\
\text { Civic principles }\end{array}$ & $\begin{array}{c}\text { Content } \\
\text { domain 3: } \\
\text { Civic participation }\end{array}$ & $\begin{array}{c}\text { Content } \\
\text { domain 4: } \\
\text { Civic identities }\end{array}$ \\
\hline \multicolumn{5}{|l|}{$\begin{array}{l}\text { Cognitive } \\
\text { domains }\end{array}$} \\
\hline Knowing & I & $\|$ & III & IV \\
\hline $\begin{array}{l}\text { Reasoning and } \\
\text { applying }\end{array}$ & $\mathrm{V}$ & $\mathrm{VI}$ & VII & VIII \\
\hline \multicolumn{5}{|l|}{$\begin{array}{l}\text { Affective- } \\
\text { behavioral } \\
\text { domains }\end{array}$} \\
\hline Attitudes & $A$ & B & $\mathrm{C}$ & $\mathrm{D}$ \\
\hline Engagement & $E$ & $\mathrm{~F}$ & $G$ & $\mathrm{H}$ \\
\hline
\end{tabular}

The following examples illustrate the mapping of items to domains (see Chapter 4 for information on the coverage of framework domains in the ICCS 2016 main survey instruments):

- A cognitive item that measures student knowledge about the role of parliament would be located in cell I (Cognitive domain: Knowing; Content domain 1: Civic society and systems).

- A cognitive item measuring student ability to identify the underlying reason for a civic protest would be found in cell VII (Cognitive domain: Reasoning and applying; Content domain 3: Civic participation).

- An affective-behavioral item asking about students' valuing of their country's flag would be located in cell D (attitude related to Content domain 4: Civic identities).

- An affective-behavioral item asking about students' trust in parliament would be located in cell A (attitude related to Content domain 1: Civic society and systems).

- An affective-behavioral item asking about students' expectations to vote in national elections would be located in cell G (engagement item related to Content domain 3: Civic participation).

- An affective-behavioral item asking about students' interest in political and social issues would be located in cell $\mathrm{E}$ (engagement item related to Content domain 1: Civic society and systems).

Open Access This chapter is distributed under the terms of the Creative Commons AttributionNonCommercial 4.0 International License (http://creativecommons.org/licenses/by-nc/4.0/), which permits any noncommercial use, duplication, adaptation, distribution and reproduction in any medium or format, as long as you give appropriate credit to the original author(s) and the source, provide a link to the Creative Commons license and indicate if changes were made.

The images or other third party material in this chapter are included in the works Creative Commons license, unless indicated otherwise in the credit line; if such material is not included in the works Creative Commons license and the respective action is not permitted by statutory regulation, users will need to obtain permission from the license holder to duplicate, adapt or reproduce the material. 